\title{
ACCEPTABILITY AND NUTRIENT CONTENT OF INSTANT DRINK MADE FROM YELLOW SWEET POTATO AND RED KIDNEY BEAN AS AN ALTERNATIVE SUPPLEMENTARY DRINK FOR PREGNANT WOMEN WITH CHRONIC ENERGY DEFICIENCY
}

\author{
Chaidir Masyhuri Majiding1*, Evy Damayanthi ${ }^{1}$, Mira Dewi ${ }^{1}$ \\ ${ }^{1}$ Community Nutrition Department, Faculty of Human Ecology, IPB University, Bogor, Indonesia \\ *E-mail: haidir1007@gmail.com
}

\begin{abstract}
Providing supplementary food or drink for pregnant women with chronic energy deficiency (CED) is one form of specific interventions to increase the nutritional intake of pregnant women which is quite effective. Supplementary drink made from local food are very appropriate to be developed by considering its nutritional and sensory aspects. This study aimed to develop and to analyze instant powder drink made from yellow sweet potato and red kidney bean as an alternative supplementary drink for pregnant women with chronic energy deficiency (CED). This study used a completely randomized factorial design with two factors and two replications. The ratio between yellow sweet potato and red kidney beans as the first factor and the addition of maltodextrin as the second factor. Results showed that from 6 formulas, formula with ratio 3:1 of yellow sweet potato and red bean also the addition of 5\% maltodextrin (F5) was chosen as the best formula. Based on acceptance test results, instant drink was accepted by pregnant women with percentage of acceptance $89.5 \%$ of overall sensory characteristics. Nutrient content analysis showed that instant drink contained $423 \mathrm{kcal}$ of energy, $3.75 \%$ of water, $1.52 \%$ of ash, $14.28 \%$ of protein, $9.92 \%$ of fat, $70.53 \%$ of carbohydrates, $7.27 \%$ of dietary fiber, $14.4 \mathrm{mg}$ of $\beta$-carotene, and $74.22 \%$ of protein digestibility. This product can be suggested as an alternative supplementary drink for CED pregnant women because it was acceptable by sensory and the nutrient content had fulfilled nutritional content requirements of supplementary food for CED pregnant women.
\end{abstract}

Keywords: pregnant women, red beans, chronic energy deficiency, instant drink, sweet potato

\section{INTRODUCTION}

Chronic energy deficiency (KEK) is a condition caused by malnutrition, especially energy and protein for a long time or chronic, characterized by mid upper arm circumference (MUAC) $<23.5 \mathrm{~cm}$. Based on the results of Indonesia Basic Health Research, the incidence of pregnant women experiencing chronic energy deficiency in 2013 was $24.2 \%$ and decreased in 2018 to $17.3 \%$ (Kemenkes RI, 2013; Kemenkes RI, 2018). Even though it has decreased, Indonesia still has moderate public health problems (10$19 \%$ ), that is problem of pregnant women at risk of chronic energy deficiency (WHO, 2010).

Provision of additional food or drink for pregnant women is one form of specific intervention to increase the nutritional intake of pregnant women which is quite effective. Based on Pastuty, et al. (2018), giving additional food to pregnant women in chronic energy deficiency gives good results in increasing the arm circumference and mother's body weight.

According to the Indonesian Ministry of Health (2010), additional food or drinks for pregnant women should be acceptable in terms of form, taste, and easy consumption. One form of additional food or drinks that can be developed is in the form of instant beverage products. The selection of instant drinks as a form of additional food or drinks is based on several advantages, namely practicality, has good product quality and stability, low production costs, suitable for largescale consumption and is easy in the distribution process so that it can be used as an alternative to additional drinks, especially for pregnant women (Susanti and Putri, 2014).

The making of instant drinks made from sweet potatoes and red beans is considered very appropriate because able to raise the potential of local food ingredients and has various nutritional contents. Almasyhuri (2009) showed that nutritious 
formula drinks based on local non-dairy foods had good acceptance. This local food-based formula drink also contain nutritional value that can meet the nutritional needs of pregnant women so that it can be used as an alternative to additional drinks that affordable to pregnant women.

Sweet potato is an alternative carbohydrate source to replace rice. In addition, there are other components contained in yellow sweet potatoes, including protein, fat, vitamins and minerals (Ginting, 2009). Red beans are a food source of protein which is widely consumed throughout the world, including Indonesia. Red beans are also a source of other nutrients such as fat, dietary fiber, carbohydrates and several important minerals, one of which is iron which is quite high. Red beans have been widely used as an ingredient to improve product quality and nutritional content in product development (Audu and Aremu, 2011). Maltodextrin is an ingredient that is often added to various food products. Based on Jittanit (2010), the reason for adding maltodextrin is because it can function in maintaining the physical and sensory properties of the product, protecting food components that are sensitive to surrounding conditions, and can increase solubility and viscosity, especially in beverage products. This study aims to analyze the acceptability and nutritional content of instant drinks from a combination of yellow sweet potato (Ipomoea batatas L.) And red beans (Phaseolus vulgaris L.) for chronic energy deficiency pregnant women (KEK).

\section{METHOD}

The design of this study was experimental study using a complete randomized design factorial with two factors, that is ratio between yellow sweet potato and kidney beans as first factor and addition of maltodextrin as second factor. Manufacture of instant drinks is carried out at Food Processing and Experiment Laboratory, IPB University. The drying process for instant drinks is carried out at IPB Seafast Center. Proximate analysis, protein digestibility, and $\beta$-carotene were carried out at Laboratory of Food Chemistry and Analysis, IPB University. The test of acceptance of beverage products was carried out at several posyandu in
Bogor City and has received ethical approval from research ethics commission involving human subjects of the Bogor Agricultural University with number 128/IT3.KEPMSM-IPB/SK/2018. This research was conducted from October 2018 to June 2019.

Yellow yam and kidney beans are the main ingredients used in making instant powder drinks. The yellow yams used are jago varieties that have harvest age of about 4-4.5 months and the red beans used are local varieties or cultivars with harvest age of about 73 days after planting. Other ingredients used as supporting materials in the manufacture of instant powder drinks include soy protein isolate, red palm oil (RPO), egg white flour, sugar flour, honey, maltodextrin and water.

This research consists of two stages that is initial stage and advanced stage. The initial stage includes designing formula, making and drying the liquid. In the next stage, analysis was carried out through organoleptic tests to determine acceptability and analysis of nutritional content of the selected formula.

Formulation design is the first stage of research. Design of formula is adjusted by nutritional content that refers to the Technical Guidelines (Juknis) of Supplementary Foods for Pregnant Women (Ministry of Health, 2017) and SNI for special drinks for pregnant women (BSN RI, 2005). Six formula were made for beverage products with two treatment factors. Composition of ingredients and determination of treatment factors, that is the ratio of yellow sweet potatoes and red beans (factor A) and the addition of maltodextrin (factor B) were carried out by trial and error until six formulas were obtained that met nutritional content reference from Technical Guidelines and SNI for special additional drinks pregnant mother. Instant powder drink formulations are presented in Table 1.

The stages of making instant powder drink based on yellow sweet potato and red beans go through several main stages, that is preparing raw material, mixing, and drying. Preparation of raw materials, yellow sweet potato and red bean, was based on modifications made by Ruben, et al. (2016) and Ticoalu (2016). The final result of preparation stage is red bean and yellow sweet potato puree. At the mixing stage, puree of yellow 
Table 1. Instant powder drink product formulation per 100 grams

\begin{tabular}{lrrrrrr}
\hline & \multicolumn{9}{c}{ Formula } \\
\cline { 2 - 7 } Ingredients & F1 & F2 & F3 & F4 & F5 & F6 \\
\hline Yellow sweet potato (g) & 20 & 30 & 10 & 20 & 30 & 10 \\
Red bean (g) & 20 & 10 & 30 & 20 & 10 & 30 \\
Red Palm Oil (RPO) (g) & 10 & 10 & 10 & 10 & 10 & 10 \\
Soy Protein Isolate (IPK) (g) & 15 & 15 & 15 & 15 & 15 & 15 \\
White egg flour (g) & 8 & 8 & 8 & 8 & 8 & 8 \\
Honey (g) & 15 & 15 & 15 & 15 & 15 & 15 \\
Sugar Powder (g) & 15 & 15 & 15 & 15 & 15 & 15 \\
Maltodextrin (g) & 10 & 10 & 10 & 13 & 13 & 13 \\
Water (ml) & 250 & 250 & 250 & 250 & 250 & 250 \\
\hline
\end{tabular}

Note:

F1: 1:1 ratio of yellow sweet potato and kidney beans without addition of maltodextrin;

F2: 3:1 ratio of yellow sweet potato and kidney beans without addition of maltodextrin;

F3: 1:3 ratio of yellow sweet potato and kidney beans without addition of maltodextrin;

F4: 1:1 ratio of yellow sweet potato and kidney beans with addition of 5\% maltodextrin

F5: 3:1 ratio of yellow sweet potato and kidney beans with addition of $5 \%$ maltodextrin;

F6: 1:3 ratio of yellow sweet potato and kidney beans with addition of $5 \%$ maltodextrin;

sweet potatoes and red beans is mixed using several other supporting ingredients, that is red palm oil, soy protein isolate, egg white flour, sugar flour, honey and water using blender. Drying stage uses drum dryer to get drink powder. The powder drink obtained is then packaged using aluminum foil 50 grams / serving.

The next stage was organoleptic hedonic test involving 30 semi-trained panelists, namely students of IPB Community Nutrition Department with the criteria of already received material abour sensory evaluation, participated in the organoleptic test and had a high sensitivity level to assess several organoleptic attributes. Panelists were asked to rate the product with the scale of 1 (very dislike) to 7 (very like) with the assessment attributes including color, aroma, taste, viscosity, mouthfeel, and product aftertaste. From six instant drink formulas, the best one will be selected for further product acceptance testing involving 100 combined pregnant women from normal pregnant women and chronic energy deficiency. The percentage of product acceptance is calculated based on the ratio of pregnant women, which gives a scale of 5 (slightly likes) to 7 (very likes).

The formula for instant powder drink selected based on the highest level of preference through the organoleptic hedonic test was also analyzed for its nutritional content to determine the contribution of nutrients to the RDA for pregnant women and energy contribution of protein. This is necessary to be able to meet the energy-protein balance in additional drinks for pregnant women in chronic energy deficiency. In addition, the nutritional content obtained is also compared with the requirements for the nutritional content of SNI for special drinks for pregnant women, technical instructions for additional food or drinks for pregnant women in chronic energy deficiency by the Ministry of Health, and 30 types of milk products for pregnant women.

The nutritional analysis of selected products includes analysis of the water content by oven method (AOAC, 2005), the ash content by gravimetric method (AOAC, 2005), the protein content by kjeldahl method (AOAC, 2005), the fat content by Soxhlet method (AOAC, 2005), the crude fiber content (AOAC, 2005), total carbohydrate content by difference method (AOAC, 2005), total dietary fiber content by enzymatic method (AOAC, 2005), $\beta$-carotene content (AOAC, 2000), and analysis of protein digestibility by in vitro method (Saunders, et al., 1973). Data processing was performed using Microsoft Excel 2010 and analyzed using SPSS version 17. Analysis of diversity used T-Test and Two-Way ANOVA difference test with Duncan advanced test $(p<0.05)$. 


\section{RESULT AND DISCUSSION}

\section{Hedonic Organoleptic Test}

The results of ANOVA analysis on hedonic organoleptic test showed that the comparison of yellow sweet potatoes and red beans and the addition of maltodextrin was significantly different $(p<0.05)$ on panelist's preference in terms of color, viscosity, taste, mouthfeel, and aftertaste. The results of Duncan test showed that the level of preference in attributes of color, viscosity, taste, mouthfeel, aftertaste and overall was higher in F5 formula. This shows that the more the proportion of yellow sweet potatoes compared to red beans (3:1) accompanied by the addition of $5 \%$ maltodextrin, the higher panelists' preference for the organoleptic attributes of the product.

In terms of color, the F5 formula has a bright yellow color. According to Yuliawaty and Susanto (2015), the addition of maltodextrin in beverage product with a slightly dark color will affect the degree of color brightness. Maltodextrin tends to give white color, so when it is mixed with yellow sweet potato and dark yellow kidney beans, it will give the product a bright color. The addition of yellow sweet potato causes the color of drink brighter because of beta-carotene content of yellow sweet potato. Therefore, the greater the proportion of yellow yam and the addition of maltodextrin in drink, the higher the color acceptance.

The larger proportion of yellow sweet potatoes in F5 formula also gives a strong intensity in terms of taste. This is in line with Nurhayati (2017) which states that drinks with a higher number of sweet potatoes have a distinctive sweet taste than sweet potatoes. Yellow yams have a high carbohydrate content which results in a sweet taste.
The carbohydrates found in sweet potatoes will break down into simple molecules (simple sugars such as sucrose, maltose and glucose) due to the heating process so that the resulting taste will sweet (Saragih, 2017).

Panelists also preferred the viscosity level in formula F5 with a higher proportion of yellow sweet potato. This is thought to come from the amylopectin content in yellow sweet potatoes which is higher than amylose. Starch with high amylopectin content will increase viscosity of the drink, while high amylose content will cause the drink to become thinner (Mahmudatussadah, 2014).

The addition of maltodextrin also affects the mouthfeel of F5. According to Yousefi (2011), maltodextrin can affect the particle size of the resulting powder to become finer. The smaller particle size has an impact on the ability to rehydrate the powder, which is easier to dissolve, so it can give a soft taste and increase the solubility of drink. The maltodextrin solution has the characteristics of a soft flavor and smooth mouthfeel so it is suitable to be added in food products to increase the quality and level of preference.

\section{Determination of the Selected Formula}

The best formula is selected from the results of hedonic organoleptic test. The higest average score of panelist's preference based on overall organoleptic parameters was formula F5 compared to other formulas. The average value of panelist's preference in F5 formula is color $(5.80=$ like $)$, aroma $(5.50=$ like $)$, viscosity $(5.30=$ rather like $)$, taste $(5.60=$ like $)$, mouthfeel $(5.30=$ rather like $)$, aftertaste $(5.10=$ a little like $)$, and overall (5.62

Table 2. Instant Drink Organoleptic Hedonic Test Result

\begin{tabular}{|c|c|c|c|c|c|c|c|}
\hline \multirow{2}{*}{ Formula } & \multicolumn{7}{|c|}{ Organoleptic Parameter } \\
\hline & Color & Aroma & Viscosity & Taste & Mouthfeel & Aftertaste & Overall \\
\hline F1 & $4.45^{\mathrm{a}}$ & $5.48^{\mathrm{a}}$ & $4.10^{\mathrm{ab}}$ & $5.15^{\mathrm{ab}}$ & $4.10^{\mathrm{a}}$ & $4.73^{\mathrm{ab}}$ & $4.75^{\mathrm{a}}$ \\
\hline F2 & $5.13^{\mathrm{bc}}$ & $5.37^{\mathrm{a}}$ & $4.83^{\mathrm{c}}$ & $5.35^{\mathrm{c}}$ & $4.88^{b}$ & $5.10 \mathrm{~b}^{\mathrm{b}}$ & $5.40^{\mathrm{b}}$ \\
\hline F3 & $4.83^{\mathrm{ab}}$ & $5.28^{\mathrm{a}}$ & $4.00^{\mathrm{a}}$ & $5.08^{\mathrm{ab}}$ & $4.33^{\mathrm{a}}$ & $4.78^{\mathrm{ab}}$ & $4.85^{\mathrm{a}}$ \\
\hline F4 & $5.40^{\mathrm{cd}}$ & $5.22^{\mathrm{a}}$ & $4.52^{\mathrm{bc}}$ & $5.18^{\mathrm{ab}}$ & $4.57^{\mathrm{ab}}$ & $4.90^{\mathrm{ab}}$ & $5.07^{\mathrm{ab}}$ \\
\hline F5 & $5.80^{\mathrm{d}}$ & $5.50^{\mathrm{a}}$ & $5.33^{\mathrm{d}}$ & $5.60^{\mathrm{c}}$ & $5.30^{\mathrm{c}}$ & $5.24^{c}$ & $5.62^{c}$ \\
\hline F6 & $5.43^{\mathrm{cd}}$ & $5.22^{\mathrm{a}}$ & $4.40^{\mathrm{abc}}$ & $4.75^{\mathrm{a}}$ & $4.40^{\mathrm{a}}$ & $4.63^{\mathrm{a}}$ & $4.85^{\mathrm{a}}$ \\
\hline
\end{tabular}

Note : Different letters in the same column indicate significant differences $(p<0,05)$. 
$=$ like). Thus, formula F5 was determined as the choosen formula because it has high average organoleptic value compared to other formula. Formula F5 is a formula with a higher proportion of yellow sweet potatoes than red beans (3: 1) accompanied by addition of $5 \%$ maltodextrin.

\section{Acceptance of the Chosen Formula}

Product acceptance test is carried out using the selected formula. The acceptance test of product involved 100 pregnant women, a combination of normal and chronic energy deficiency pregnant women as panelists. Panelist's preferences for the overall product were obtained based on the number of assessment scores given by panelists with the following percentages: $20 \%$ of the color score, $20 \%$ of the aroma score, $30 \%$ of the taste score, $10 \%$ of the viscosity score, $10 \%$ of the

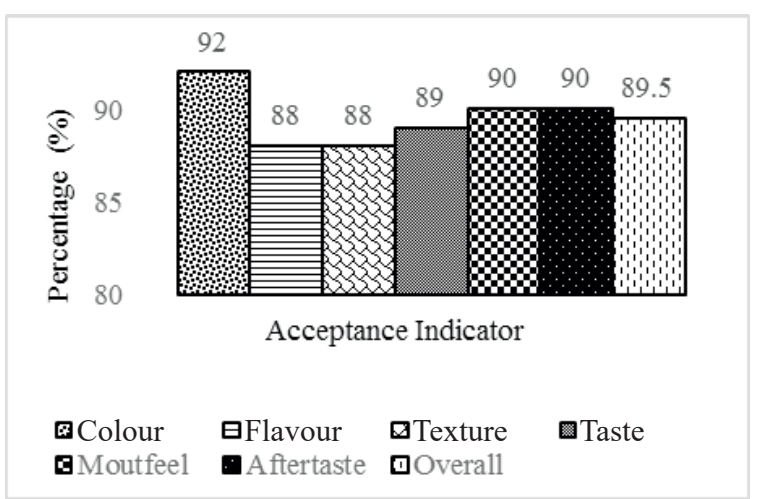

Figure 1. Percentage of acceptance of selected instant drink products by pregnant women mouthfeel score, and $10 \%$ of the aftertaste score. The percentage of product acceptance is calculated based on ratio of pregnant women who give a scale of (5) rather like, (6) like, and (7) very like.

The results of analysis show that percentage of panelist's acceptance of instant powder drink products is $92 \%$ in taste attribute, $88 \%$ for aroma attribute, $88 \%$ for texture attribute, $89 \%$ for taste attribute, $90 \%$ for mouthfeel attribute, $90 \%$ for aftertaste attribute, and overall of $89.5 \%$. These results indicate that beverage products given to 100 pregnant women can be well received because the percentage of overall acceptance that likes the product has been more than $50 \%$ (Setyaningsih, 2010).

\section{Nutritional Content of the Selected Formula}

Based on the analysis of nutrient content, the selected beverage formula has energy content of $423 \mathrm{kcal}$, water content of $3.75 \%$, ash content of $1.52 \%$, protein content of $14.28 \%$, fat content of $9.92 \%$, carbohydrates of $70.53 \%$, total fiber of $7.27 \%$, beta-carotene levels of $14.4 \mathrm{mg} / 100 \mathrm{~g}$, and protein digestibility of $74.22 \%$. The nutrient content in selected formula has fulfilled the RDA contribution for snack food or drink, which ranges from $15-20 \%$. The nutritional content in selected formula has also met the nutritional content requirements of additional foods or drinks for chronic energy deficiency pregnant women based on SNI for special drinks for pregnant women and

Table 3. Nutritional Content of the Selected Formula per 100 gram

\begin{tabular}{|c|c|c|c|c|}
\hline Nutrient & Content & $\begin{array}{l}\text { Ttechnical } \\
\text { instructions for } \\
\text { additional foods or } \\
\text { drinks for chronic } \\
\text { energy deficiency } \\
\text { pregnant women. } \\
\text { (Kemenkes 2017) }\end{array}$ & $\begin{array}{l}\text { on SNI for special } \\
\text { drinks for pregnant } \\
\text { women (BSN 2005) }\end{array}$ & $\%$ RDA \\
\hline Water (\%) & 3.75 & - & Maks. 4 & - \\
\hline Ash $(\%)$ & 1.52 & - & Maks. 6 & - \\
\hline Protein $(\%)$ & 14.28 & Min. 6 & $18-25$ & 18.79 \\
\hline Fat $(\%)$ & 9.92 & Min. 12 & Min. 3.50 & 11.81 \\
\hline Carbohydrate (\%) & 70.53 & - & Maks. 65 & 20.44 \\
\hline Energy (kcal) & 423 & Min. 270 & Min. 370 & 17.05 \\
\hline Dietary Fiber (\%) & 7.27 & Min. 5 & - & 20.77 \\
\hline$\beta$-carotene (mg) & 14.40 & - & - & - \\
\hline Protein Digestibility (\%) & 74.22 & - & - & - \\
\hline
\end{tabular}


technical instructions for additional foods or drinks specifically for chronic energy deficiency pregnant women.

The ash content value of instant powder drink products was $1.52 \%$. This shows that in every 100 $\mathrm{g}$ of product there are $1.52 \mathrm{~g}$ of mineral elements. The value of ash content in instant drink products is still classified as normal because it does not exceed $6 \%$ ash content based on SNI for special drinks for pregnant women (BSN RI, 2005). The value of ash content in foodstuffs is able to reflect the quality of foodstuffs related to certain metal contaminants. The higher the ash content, the higher the level of metal contamination which can affect the safety and quality of food (Andarwulan, et al., 2011).

Instant drink products have protein content of $14.28 \%$. During pregnancy, the fulfillment of protein requirements is needed to support increased protein synthesis which functions to maintain maternal tissue and fetal growth, especially in the third trimester. Provision of additional food (PMT) is needed as an effort to increase protein intake in pregnant women, especially those experiencing chronic energy deficiency (Kristiyanasari 2010). Therefore, provision of additional food generally has a fairly high protein content. The protein content in the product has met the technical guidelines for providing additional food or drink for chronic energy deficiency pregnant women, which is at least $6 \mathrm{~g}$ (Kemenkes RI, 2017). The protein content in instant drink products is quite high when compared to similar products for chronic energy deficiency pregnant women, which is nuts and milk formula drinks of $5.3-7 \mathrm{~g} / 100 \mathrm{~g}$ and additional food products from the government, that is $10.14 \mathrm{~g} / 100 \mathrm{~g}$ (Indonesian Ministry of Health, 2017; Utami, et al., 2017).

The analysis showed that protein content contributed $13.31 \%$ to the total energy of beverage products. According to WHO (2018), providing additional food or drink with balanced protein energy has protein less than $25 \%$ of total energy. For chronic energy deficiency pregnant women, protein has been shown to increase pregnancy weight and improve pregnancy outcome. A metaanalysis research conducted by Liberato, et al (2013) also states that balanced protein energy supplementation reaches $20 \%$ of energy, can increase fetal growth, birth weight (by 95-324 g) and height (by 4.6-6.1 $\mathrm{mm}$ ), as well as reducing percentage of low birth weight (by 6\%). Balanced protein energy supplementation during pregnancy that is less than $20 \%$ (12.3\% protein) results in higher fetal growth compared to supplementation containing $22.4 \%$ protein. The percentage of energy from protein of $13.31 \%$ can provide benefits or have a positive impact on fetal development and growth.

Fat is one of the essential nutrients to be consumed during pregnancy because it can provide energy and help build many fetal organs and placenta (Okubo, et al., 2011). The fat content of instant drink products is $9.92 \%$. These results do not meet the technical guidelines for providing additional food or drink for pregnant women with a minimum of $12 \mathrm{~g}$ (Indonesian Ministry of Health, 2017), but have met the requirements of SNI for pregnant women, which is a minimum of $3.50 \mathrm{~g}$ of fat content (BSN RI, 2005). ). Based on Utami, et al. (2017), nuts and milk drink products for pregnant women also have a relatively low fat content, namely $1-3.8 \%$ each. The low fat content is due to the less homogeneous oil in the drink so that the oil tends to be less stable (a lot is wasted) during the drying process.

Carbohydrate content of instant drink products is $70.53 \%$. Carbohydrate content in the product is thought to come from the contribution of yellow sweet potatoes and red beans which are used as raw material. Carbohydrates are the dominant nutrient in yellow sweet potatoes where per 100 g contains $88.32 \mathrm{~g}$ carbohydrates (Endrias, et al., 2016). Meanwhile, red beans contain $56.70 \mathrm{~g}$ of carbohydrates per $100 \mathrm{~g}$ (Chaudary and Sharma, 2013). The addition of other ingredients such as maltodextrin, sugar and honey also contributes to carbohydrate content of the product.

The need for energy during pregnancy is necessary for the growth of fetus in womb. Therefore, energy needed also increases to support fetal growth and development as well as maternal health (Syari, et al., 2015). Energy content of the yellow sweet potato and red bean powder drink products is $429 \mathrm{kcal}$. This value has met the requirements for energy content of beverage products or additional food for pregnant women in chronic energy deficiency, which is a minimum 
of $270 \mathrm{kcal}$ (Kemenkes RI, 2017). In addition, the energy content of this beverage product also meets the requirements for additional energy from additional food and drink including nutrient dense drinks, which is $400 \mathrm{kcal}$ (Damajanti, 2015).

The results of the analysis showed total dietary fiber content in beverages were $7.27 \%$ or in $100 \mathrm{~g}$ of products contain $7.27 \mathrm{~g}$ of dietary fiber. Based on these results, yellow sweet potato and red bean powder drink products can be claimed as high food fiber products because it has total dietary fiber more than $6 \mathrm{~g}$ per $100 \mathrm{~g}$, in accordance with the provisions of BPOM RI regarding claims and labels for processed food in Indonesia (BPOM RI, 2016). Yellow yams and red beans contribute to fiber content of products, which contain 3.59 grams of fiber in yellow sweet potatoes and red beans contain 4 grams of fiber (Endrias, et al. 2016; Chaudary and Sharma, 2013).

The result of $\beta$-carotene analysis of selected formula is $14400 \mathrm{mcg} / 100 \mathrm{~g}$ or equivalent to 1200 mcg RAE/100 g vitamin A. Based on BPOM $\mathrm{RI}$, a food product can be claimed to be high or rich in vitamin $A$ ( $\beta$-carotene) if it meets at least 30\% Nutrition Label Reference of vitamin A for pregnant women. To meet $30 \%$, at least product contain $245 \mathrm{mcg}$ RAE or equivalent to $2938 \mathrm{mcg} / 100 \mathrm{~g} \beta$-carotene. This shows that the beverage product can fulfill the high $\beta$-carotene claim because it has met the requirement for $30 \%$ vitamin A based on Nutrition Label Reference. $\beta$-carotene is also known as provitamin $\mathrm{A}$. $\beta$-carotene is converted into retinol (vitamin $\mathrm{A}$ ) in the intestinal mucosa with the help of an enzyme derived from intestinal cell cytosol. In pregnancy, vitamin $\mathrm{A}$ is needed by second trimester pregnant women to maintain immunity, maintain healthy bones, teeth, skin and hair while for the fetus it is useful for nerves in the brain, forming cell membranes and vision (Preedy, 2012).

The protein digestibility of selected formula was $74.22 \%$. According to Sediaoetama (1991), high protein digestibility in food products ranges from $\geq 80 \%$. The low protein digestibility in drinks is caused by the type of protein used. Most of the types of protein used in the study were vegetable protein, except for egg white flour, which included animal protein. Vegetable protein that enters body is not completely digested. Vegetable protein is not digested completely because it is protected by protective cellulose and polysaccharides which cannot be digested by digestive enzymes, so that the digestibility of vegetable proteins is generally lower than animal sources (Diana, 2010).

Other factors that can affect protein digestibility include interaction of protein with polyphenols, phytates, carbohydrates, fats, and anti-nutritional substances (Duodu, et al., 2013). Heating process in beverage-making process is thought to affect the digestibility of the protein. Heating triggers protein denaturation. Excessive heating will cause the protein to lose its binding structure (protein folding) so that some molecules will separate with their insoluble sub-units. Furthermore, these molecules combine and form an aggregate. The results of protein aggregation limit access to peptide bonds for hydrolytic enzymes (proteases) so that protein digestibility decreases (Gulati, et al., 2017).

The selected formula contributed $17.05 \%$ of energy, $18.79 \%$ protein, $11.81 \%$ fat, $20.44 \%$ carbohydrates, and $20.77 \%$ total dietary fiber of nutritional adequacy rate for pregnant women. The nutritional value of selected drink products is able to meet the nutritional needs of pregnant women for a portion of a snack. The nutritional content of food at least meets $10-20 \%$ of daily nutritional needs for a snack (Almatsier, 2010). Based on this, instant drinks based on yellow sweet potatoes and red beans can be used as an alternative supplementary drink for pregnant women because they meet the nutritional needs of pregnant women in a day for drinks or snacks.

\section{CONCLUSION}

The chosen instant powder drink product was F5 with a ratio of 3: 1 yellow sweet potato and kidney beans along with $5 \%$ addition of maltodextrin. Based on overall organoleptic characteristics, $89.5 \%$ of pregnant women accepted the selected instant drink products. Selected instant beverage products have an energy content of 423 kcal, $3.75 \%$ water content, $1.52 \%$ ash content, $14.28 \%$ protein content, $9.92 \%$ fat content, $70.53 \%$ carbohydrate content, $7 \mathrm{~g}$ total food fiber, $27 \%$, beta-carotene $14.4 \mathrm{mg} / 100 \mathrm{~g}$, and protein digestibility of $74.22 \%$. The nutritional content 
of selected instant drink products has met the nutritional content requirements of additional food for chronic energy deficiency pregnant women, SNI for pregnant women, and the requirement for pregnant women to drink or snack.

For future research, beverage products can be added flavor variants to increase product acceptance by pregnant womoen. The addition of encapsulated MMN (Multi-Micro Nutrient) also needs to be added in the future to increase and prevent loss of mineral content of beverage products. In addition, it is necessary to do other processing methods to reduce the water content of these powdered beverage products such as using spray dryer method which is quite effective in reducing water content.

\section{ACKNOWLEDGEMENT}

Author would like to thank Ministry of Health of Republic of Indonesia for funding this research as part of research project entitled "Development of Local Food Products for Stunting Prevention in Intervention Package for Nutritional Problems and Application of 1000 years of life in West Java Region in 2018" chaired by Prof. . Dr. Ir. Sri Anna Marliyati, MS (Department of Community Nutrition, IPB).

\section{REFERENCES}

Almasyhuri, Imaningsih, N., Purawisastra, S., Affandi, E., \& Nurjanah, N. (2008). Pengembangan minuman formula ibu hamil dan meneteki berbasis bahan lokal non-susu. Penelitian Gizi dan Makanan, 31(1), 42-50.

AOAC. (2000). Official methods of analysis of aoac international 17th ed. Arlington Va, US: AOAC International.

AOAC. (2005). Official methods of analysis of aoac international 18th ed. Arlington Va, US: AOAC International.

Almatsier, S. (2010). Prinsip dasar ilmu gizi. Jakarta: Gramedia Pustaka Utama.

Andarwulan, N., Kusnandar, F., \& Herawati, D. (2011). Analisis pangan. Jakarta: PT. Dian Rakyat.

Audu, S.S., \& Aremu, M.O. (2011). Effect of processing on chemical composition of red kidney bean (Phaseolus Vulgalris L.) Flour. PJN, 10(11), 1069-1075.
BPOM RI. (2016). Peraturan Kepala Badan Pengawas Obat dan Makanan Republik Indonesia Nomor 13 Tahun 2016 tentang Pengawasan Klaim pada Label dan Iklan Pangan Olahan. Jakarta: Badan Pengawas Obat dan Makanan Republik Indonesia.

BSN RI. (2005). SNI 01-7148-2005 tentang SNI Minuman Khusus Ibu Hamil dan atau Ibu Menyusui. Jakarta: Badan Standarisasi Nasional Republik Indonesia.

Chaudhary, R., \& Sharma, S. (2013). Conventional nutrients and antioxidants in red kidney beans (phaseolus vulgaris 1.): an explorative and product development endeavor. Food Science and Technology, 14(2), 275-285.

Damajanti, M. (2015). Pedoman Penanggulangan Kurang Energi Kronis (KEK) pada Ibu Hamil. Jakarta: Direktorat Bina Gizi dan KIA Kemenkes RI.

Diana, F.M. (2010). Fungsi dan metabolisme protein dalam tubuh manusia. Jurnal Kesehatan Masyarakat, 4(1), 47-52.

Duodu, K.G., Taylor, J.R.N., Belton, P.S., \& Hamaker, B.R. (2013). Factors affecting sorghum protein digestibility. $J$ of Cereal $S c i$, $38,117-131$.

Endrias, D., Negussie, R., \& Gulelat, D. (2016). Comparison of three sweet potato (ipomoea batatas (1.) lam) varieties on nutritional and antinutritional factors. Global Journal of Science Frontier Research, 16(4), 62-72.

Ginting, E. (2006). Teknologi pasca panen ubi jalar mendukung diversifikasi pangan dan pengembangan agroindustri. Balitkapi Malang Bul Palawija, 11, 15-28.

Gulati, P., Li, A., Holding, D., Santra, D., Zhang, Y., \& Rose, D.J. (2017). Heating reduces proso millet protein digestibility via formation of hydrophobic aggregates. J. Aggric. Food Chem, $65,1952-1959$.

Kemenkes RI. (2010). Pedoman gizi ibu hamil dan pengembangan makanan tambahan ibu hamil berbasis pangan lokal. Jakarta: Direktorat Bina Gizi Masyarakat, Kementerian Kesehatan RI.

Kemenkes RI. (2013). Laporan Riset Kesehatan Dasar (Riskesdas) 2013. Jakarta: Kementerian Kesehatan Republik Indonesia.

Kemenkes RI. (2017). Petunjuk teknis pemberian makanan tambahan (balita-ibu hamil-anak sekolah). Jakarta: Kementerian Kesehatan Republik Indonesia. 
Kemenkes RI. (2018). Buku Saku Pemantauan Status Gizi tahun 2017. Jakarta: Kementerian Kesehatan Republik Indonesia.

Khomsan, A., \& Eddy, S.M. (2009). Pengetahuan, Sikap dan Praktek Gizi Ibu Beserta Posyandu. Jurnal Gizi dan Pangan, 4(1), 33-41.

Kristiyanasari, W. (2010). Gizi Ibu Hamil. Yogyakarta: Nuha Medika Press.

Liberato, S.C., Gurmeet, S., \& Kim, M. (2013). Effects of protein energy supplementation during pregnancy on fetal growth: a review of the literature focusing on contextual factors. Food \& Nutrition Research, 57(1), 1-13.

Mahmudatussadah,A. (2014). Komposisi kimia ubi jalar (Ipomoea Batatas L.) pada berbagai waktu simpan sebagai bahan baku gula cair. Pangan, 23(1), 53-64.

Nurhayati, N., Naili, M.R., \& Miftahul, C. (2017). Formulation of powder drink made from taro starch and sweet potato flour. Balitkabi Litbang Pertanian, 7(1), 694-705.

Nurina, R. (2016). Program pemberian makanan tambahan untuk peningkatan status gizi ibu hamil dan balita di Kecamatan Cilamaya Kulon dan Cilamaya Weton, Karawang. Jurnal Care, 1(1), 44-49.

Okubo, H., Yoshihiro, M., Satoshi, S., Keiko, T., \& Kentaro. (2011). Maternal dietary pattern in pregnancy and fetal growth in japan: The Osaka Maternal and Child Health Study. British Journal of Nutrition, 2012(107), 1526-1533.

Pastuty, R., Rochmah, K.M., \& Herawati, T. (2018). Efektifitas program pemberian makanan tambahan pemulihan pada ibu hamil kurang energi kronik di Kota Palembang. Jurnal Ilmu Kesehatan Masyarakat, 9(3), 179-188.

Preedy, V.R. (2012). Vitamin a and carotenoids (chemistry, analysis, function and effects). United Kingdom: The Royal Society of Chemistry.

Profir, A.G., \& Vizireanu, C. (2013). Sensorial analysis of a functional beverage based on vegetables juice. Acta Biol Szeged, 57(2), 145148.

Ritchie, L.D., \& King, J.C. (2008). Nutrient recommendation and dietary guidelines for pregnant women. In: Lammi-Keefe CJ, Couch SC, Philipson EH (eds.) Handbook of Nutrition and Pregnancy: Nuntrition and Health. Totowa: Humana Press.

Ruben, E., Wisaniyasa, N.W., \& Pratiwi, D.K. (2016). Studi sifat fisik, kimia dan fungsional tepung kacang merah dan tepung tempe kacang merah (phaseolus vulgaris 1.). Jurnal Ilmu dan Teknologi Pangan, 5(1), 1-11.

Saragih, C., Netti, H., \& Raswen, E. (2017). pembuatan sirup ubi jalar ungu (ipomea batatas 1.) dengan penambahan sari lemon (citrus limon 1.). JOM Faperta UR, 4(1), 1-15.

Saunders, R.M., Connor, M.A., Booth,A.N., Bickoff, E.M., \& Kholer, G.O. (1973). Measurement of digestibility of alfafa protein concentrates by in vivo and in vitro methods. J. Nutr, 103(4), 530-535.

Sediaoetama, A.D. (1991). Ilmu Gizi untuk Mahasiswa dan Profesi. Jakarta: Dian Rakyat.

Setyaningsih, D., Apriyanto, A., \& Sari, M.P. (2010). Analisis Sensori untuk Industri Pangan dan Agro. Bogor: IPB Press.

Susanti, Y.I., \& Putri, W.D.R. (2014). Pembuatan minuman serbuk markisa merah (passiflora edulis f. edulis sims) (kajian konsentrasi tween 80 dan suhu pengeringan). Jurnal Pangan dan Agroindustri, 2(3), 170-179.

Syari, M., Serudji, J., \& Mariati, U. (2015). Peran asupan zat gizi makronutrien ibu hamil terhadap berat badan lahir bayi di Kota Padang. Jurnal Kesehatan Andalas, 4(3), 729-736.

Ticoalu, G.D., Yuanianta, \& Maligan, J.M. (2016). The utilization of purple sweet potato (ipomoea batatas) as an anthocyanin contained beverage using enzimatic hydrolisis process. Jurnal Pangan dan Agroindustri, 4(1), 46-55.

Utami, N.W., Majid, T.H., \& Herawati, D.M.D. (2017). Pemberian minuman formula kacang merah, kacang tanah, dan kacang kedelai terhadap status gizi ibu hamil kurang energi kronis (KEK). Jurnal Gizi Klinik Indonesia, 14(1), 1-9.

WHO. (2011). Nutrition Landscape information system (nlis), country profile indicators, interpretation guide. Geneva: World Health Organization.

WHO. (2018). High-protein supplementation during pregnancy. Retrieved from https://www. who.int/elena/titles/high-protein-pregnancy/ en/

Yousefi, S., Emam-Djomeh, Z., \& Mousavi, M.S. (2011). Effect of carrier type and spray drying on the physicochemical properties of powdered and reconstituted pomegranate juice (Punica Granatum L.). Journal of Food Science and Technology, 48(6), 677- 684.

Yuliawaty, S.T., \& Susanto, W.H. (2015). Pengaruh 
lama pengeringan dan konsentrasi maltodekstrin terhadap karakteristik fisik kimia dan organoleptik minuman instan daun mengkudu (Morinda Citrifolia L.). Jurnal Pangan dan Agroindustri, 3(1), 41-52. 